\title{
IDENTIFICATION AND EVALUATION OF THE CRITICAL SUCCESS FACTORS FOR CONSTRUCTION PROJECTS IN LITHUANIA: AHP APPROACH
}

\author{
Neringa GUDIENÉ $\dot{\mathrm{a}}^{\mathrm{a}}$, Audrius BANAITIS ${ }^{\mathrm{a}}$, Valentinas PODVEZKO ${ }^{\mathrm{b}}$, Nerija BANAITIENE ${ }^{\mathrm{a}}$ \\ ${ }^{a}$ Department of Construction Economics and Property Management, Faculty of Civil Engineering, \\ Vilnius Gediminas Technical University, Sauletekio al. 11, 10223 Vilnius, Lithuania \\ ${ }^{b}$ Department of Mathematical Statistics, Faculty of Fundamental Sciences, \\ Vilnius Gediminas Technical University, Sauletekio al. 11, 10223 Vilnius, Lithuania
}

Received 31 Dec 2012; accepted 08 Apr 2014

\begin{abstract}
This paper proposes the Analytic Hierarchy Process (AHP) as a tool to rank different critical success factors (CSFs) for construction projects in Lithuania. Considering the current lack of understanding of CSFs within the local context, this study is one of the first attempts to gain an understanding of the CSFs in the local industry. Our study revealed that, for construction projects in Lithuania, clear and realistic project goals, project planning, the project manager's competence, relevant past experience of the project management/team, the competence of the project management/team, clear and precise goals/objectives of the client, the project's value, the project's complexity and uniqueness, the project manager's experience, and the client's ability to make timely decisions are the top-ranking CSFs. In view of these findings, the study highlighted the key areas for successful implementation of construction projects in Lithuania.
\end{abstract}

Keywords: critical success factors, construction project, AHP, ranking, Lithuania, project success.

Reference to this paper should be made as follows: Gudienė, N.; Banaitis, A.; Podvezko, V.; Banaitienė, N. 2014. Identification and evaluation of the critical success factors for construction projects in Lithuania: AHP approach, Journal of Civil Engineering and Management 20(3): 350-359. http://dx.doi.org/10.3846/13923730.2014.914082

\section{Introduction}

Construction is one of the largest sectors in Lithuania's economy. It contributed approximately $5.9 \%$ of the country's gross domestic product in 2012 (Statistics Lithuania 2013a). The sector comprises of 16,995 enterprises covering 89,000 jobs, which is equivalent to about $7 \%$ of the total employment in Lithuania (Statistics Lithuania 2013b). To carry into effect the Programme for the Refurbishment (Modernisation) of Apartment Buildings approved by the Government in 2004, investments of LTL 1.2bn in 2012-2015 and LTL 2.5bn in 2016-2020 are planned for the refurbishment (Government of the Republic of Lithuania 2013). The refurbishment projects for apartment buildings are expected to spur long-term growth in the country's economy.

The fragmented nature of the construction sector, however, is determined by the fact that construction involves a variety of enterprises engaged in traditionally separate activities (design, construction, operation, and maintenance), by one-off nature of construction projects, by high percentage of sub-contracting, etc. This leads to poor coordination and management, which, in turn, plays part in quality, financing, collaboration, mutual sharing of lessons learned and other issues.

Success has always been the ultimate goal of every activity and a construction project is no exception. Project success has eluded the construction sector to the point where keeping existing clients has become a battle, let alone attracting new clients. Large and complex construction projects are becoming more difficult to complete successfully (Garbharran et al. 2012).

There is no an industry-accepted or standardised definition of project success because the fact is that individual project teams find themselves in unique situations, implying that their definition of success will differ from that of another project team. Project success is a topic that is frequently discussed and yet rarely agreed upon (AlTmeemy et al. 2010; Yong, Mustaffa 2012, 2013). According to Nguyen et al. (2013), project success is a foundation to manage and control current projects, and to plan and orient future projects. The success of the project as a temporary organization is affected by the resources and effectiveness of the corporate organizations; and the success of the organization is also affected by the performance and success of every individual project (Zavadskas et al. 2012, 2014).

One approach to studying project success is to focus on factors leading to the project success. Over the past few decades, numerous lists and models have been proposed in the literature regarding critical success factors. Rockart (1982) was the first person to define the concept of critical success factors. He defined the critical success factors as "the limited number of areas in which results, if 
they are satisfactory, will ensure successful competitive performance for the organization". Critical success factors are those inputs to the project management system that directly increase the likelihood of achieving project success (Garbharran et al. 2012).

There are a great number of researchers interested in studying the factors which influence project success, and in criteria to measure project success.

The role of a project leader is significant to project success; this fact has been demonstrated by various studies covered in literature (Yang et al. 2011; Nixon et al. 2012; Hwang, $\mathrm{Ng}$ 2013). It is important for the project leadership to develop an effective project strategy to increase the likelihood of project success. Project leadership must possess essential leadership and managerial knowledge, skills, competencies and characteristics which ensure successful projects completion by taking right decisions at right time and involving right people at right places (Ahmed et al. 2013). According to Ibrahim et al. (2013), successful projects are the product of well integrated teams. They identified $15 \mathrm{key}$ practice indicators of team integration in construction projects. Meng (2012) highlighted the importance of effective relationship management to project success. Construction processes planning and effective management are extremely important for success in construction business (Zavadskas et al. 2014). Ribeiro et al. (2013) also analysed the critical success factors for project management in the construction industry. Yang et al. (2012) assessed impacts of information technology on project success through knowledge management practice. The results showed that team relationship and team size have a moderating effect on the relationship between knowledge management and project success. Ismail et al. (2012) determined the influential safety factors that governed the success of a safety management system for construction sites. From the survey it was found that the most influential safety factor was personal awareness followed closely by communication. Aksorn et al. (2008) identified and ranked 16 critical success factors of safety programs. "Management support" proved to be the most influential factor for safety program implementation. Al Haadir and Panuwatwanich (2011) admitted that successful implementation of safety programs in construction projects affects project success. They identified seven most critical safety factors: (1) management support; (2) clear and reasonable objectives; (3) personal attitude; (4) teamwork; (5) effective enforcement; (6) safety training; and (7) suitable supervision. Hwang et al. (2013) identified the critical factors affecting schedule performance of public housing projects. The study revealed that "site management", "coordination among various parties", and "availability of labourers on site" were the top three factors affecting schedule performance of public housing projects. According to Memon et al. (2012), cost performance is the basic criteria for measuring success of any project. Since construction projects are highly dependable on resources, construction cost is significantly affected by various resource related factors. Doloi et al. (2012) analysed the critical factors affecting delays in construction projects. This research revealed that one of the most critical factors of construction delay is the lack of commitment. According to Sotoodeh Gohar et al. (2012), analysing critical causes of failure and success in construction projects is one of useful methods in identification of risk factors. Ghoddousi and Hosseini (2012) indicated that the most important factors affecting sub-contractors productivity include: materials/tools, construction technology and method, planning, supervision system, reworks, weather, and jobsite condition. Tan and Ghazali (2011) determined 40 critical success factors for contractors and grouped under seven main categories: (1) project management factors; (2) procurement related factors; (3) client-related factors; (4) design team-related factors; (5) contractorrelated factors; (6) project manager-related factors; and (7) business and work environment-related factors. According to Huang (2011) and Alzahrani and Emsley (2013), construction contractors have big influences upon projects and their successes. Therefore, it is quite critical to select a qualified contractor in the process of construction management. A competent construction contractor is one of the indispensable conditions of a proper process and completion of a construction project.

Based on the analysis of the literature outlined earlier, it is apparent that there are plenty of factors with the potential to affect the project success. This paper presents the main findings of a recent study that investigated the critical success factors affecting the implementation of projects in construction enterprises in Lithuania. This study employed the analytic hierarchy process (AHP) approach in an attempt to identify and evaluate the critical success factors for construction projects. A generic hierarchy model was developed to prioritize these factors.

\section{Methodology}

This study consisted of two surveys: a general survey and the AHP survey. First, based on the literature review and on our own experience, a total of 71 project success factors were established. The success factors were classified into seven groups: external factors, institutional factors, project related factors, project management/team related factors, project manager related factors, client related factors, and contractor related factors. In the general survey, 27 construction professionals and experts with knowledge and experience in project management were asked to rate the proposed success factors. The 5-point Likert scale was adopted, where 1 represents "not important", 2 - "less important", 3 - "important", 4 - "more important", and 5 - "most important", to capture the importance, or weights, of the critical success factors for construction projects in Lithuania. To determine the relative ranking of the critical success factors, the scores were then transformed to importance indices. The results of Relative Importance Index (RII) calculation and the ranks of CSFs can be found in Gudienè et al. (2013).

Figure 1 illustrates the research methodology of the study. 


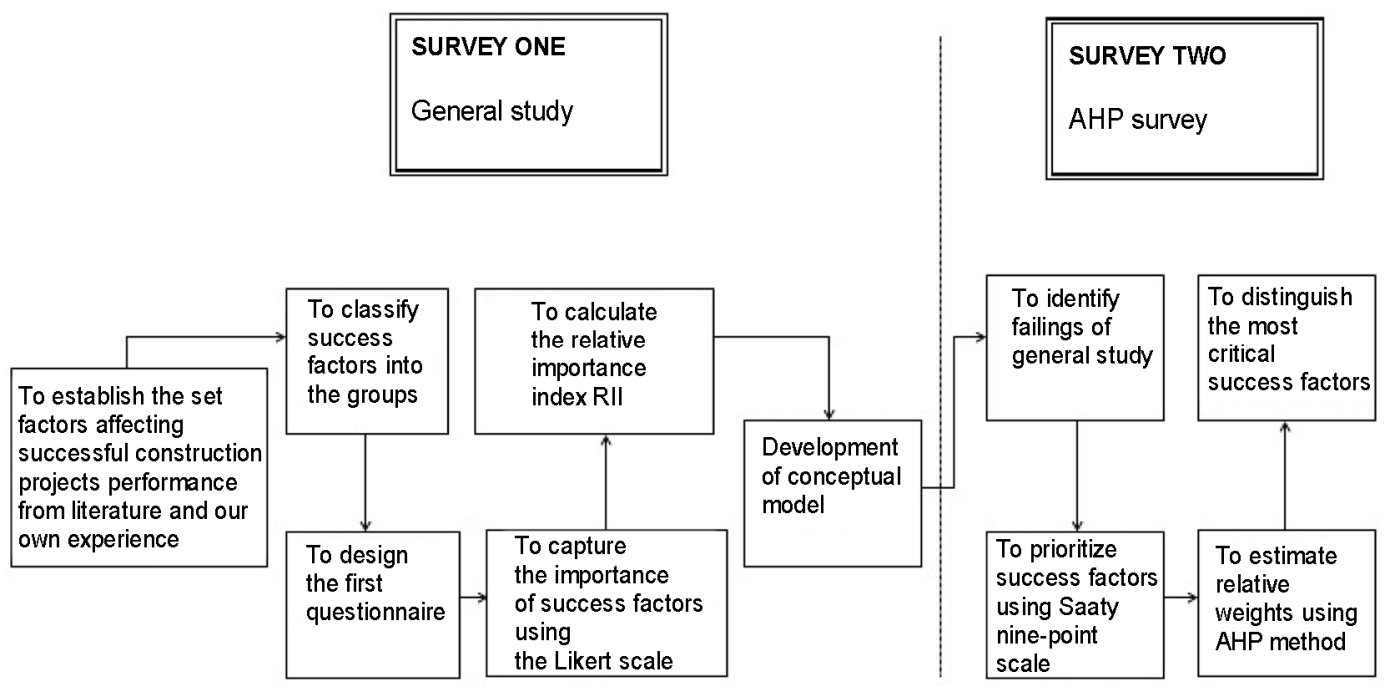

Fig. 1. The research methodology

The results of the earlier study show that measuring the relative importance index is a widely used technique, but has some limitations:

1. Experts often scored the factors equally (giving 4 or 5 points), because they had to work on a five-point scale and all factors they had to assess were highly important with a tangible impact on project implementation. The RII method is affected by the psychological factor.

2. Although the experts had to assess each group of factors separately, quite a few factors from different groups were, for the reasons mentioned in point 1 above, given the same weights even though their effect on project implementation obviously differed.

To improve the assessment framework and to rank the factors by their importance (weight) better achieving a more precise judgement of their effect on project implementation, we propose:

a) to expand the scale,

b) to advise the experts to make preliminary rankings of the factors in each separate group taking into account the purpose of the assessment, i.e. project implementation, thus highlighting they key factors and preventing individual factors from getting equal ranking.

A more extensive assessment system ( 9 points) is used in the Analytic Hierarchy Process (AHP), a mathematically validated approach (Saaty 1980, 1990). AHP is a powerful and flexible method that uses a hierarchic structure to present a complex decision problem by decomposing it into several smaller subproblems.

AHP has been successfully applied in many construction-industry studies (Sotoodeh Gohar et al. 2012; Tan, Ghazali 2011; Al Haadir, Panuwatwanich 2011; Raisbeck, Tang 2013; Aminbakhsh et al. 2013; Bitarafan et al. 2012; Cheng 2013; Chou et al. 2013; Fouladgar et al. 2012; Hashemkhani Zolfani et al. 2012; Kuzman et al. 2013; Lai 2012; Rezaeiniya et al. 2012; YazdaniChamzini et al. 2013), because it is a useful tool in dealing with multi-criteria decision-making problems. Sotoodeh Gohar et al. (2012) presented a quantitative method based on the fuzzy AHP approach to manage the risk of construction projects in the uncertain environment. Al Haadir and Panuwatwanich (2011) used AHP to prioritise critical factors affecting the successful implementation of safety programs among construction companies in Saudi Arabia. According to Raisbeck and Tang (2013), in construction management research the AHP method has often been presented as a decision support tool (e.g. contractor selection) rather than an investigative or evaluation tool. They used this method as an investigative tool to identify relevant factors in the design development of complex projects. Aminbakhsh et al. (2013) assessed safety risk using AHP during planning and budgeting of construction projects. The AHP method was used by Bitarafan et al. (2012) for calculating the relative importance of the criteria and their weights for cold-formed steel structures for reconstructing the damaged areas. Cheng (2013) adopted the fuzzy AHP method to obtain the opinions of professionals on the selection of technology valuation methods for the development of new materials. Chou et al. (2013) employed the fuzzy AHP to determine the weights of the factors that influence the cost of a construction project. In Fouladgar et al. (2012) the fuzzy AHP is utilized to calculate the weights of the evaluation criteria for maintenance strategy selection. Hashemkhani Zolfani et al. (2012) used AHP to calculate the weights of the evaluation criteria for selecting a supplier. Kuzman et al. (2013) compared the types of passive house construction using AHP. Yazdani-Chamzini et al. (2013) proposed the integrated AHP-COPRAS method to select the most appropriate renewable energy project among the feasible alternatives.

The first step in AHP is to develop a hierarchical structure to define a single pre-defined goal and potential factors supporting each factor group. Figure 2 shows the proposed hierarchical tree to prioritize and evaluate the CSFs. The identified CSFs are categorized in seven main groups and a hierarchy structure of their factors is provided. Factors may be attributed different rankings with the help of the simple method of pairwise comparison (Zavadskas, Kaklauskas 2007) in which the factors $R_{i}$ and 


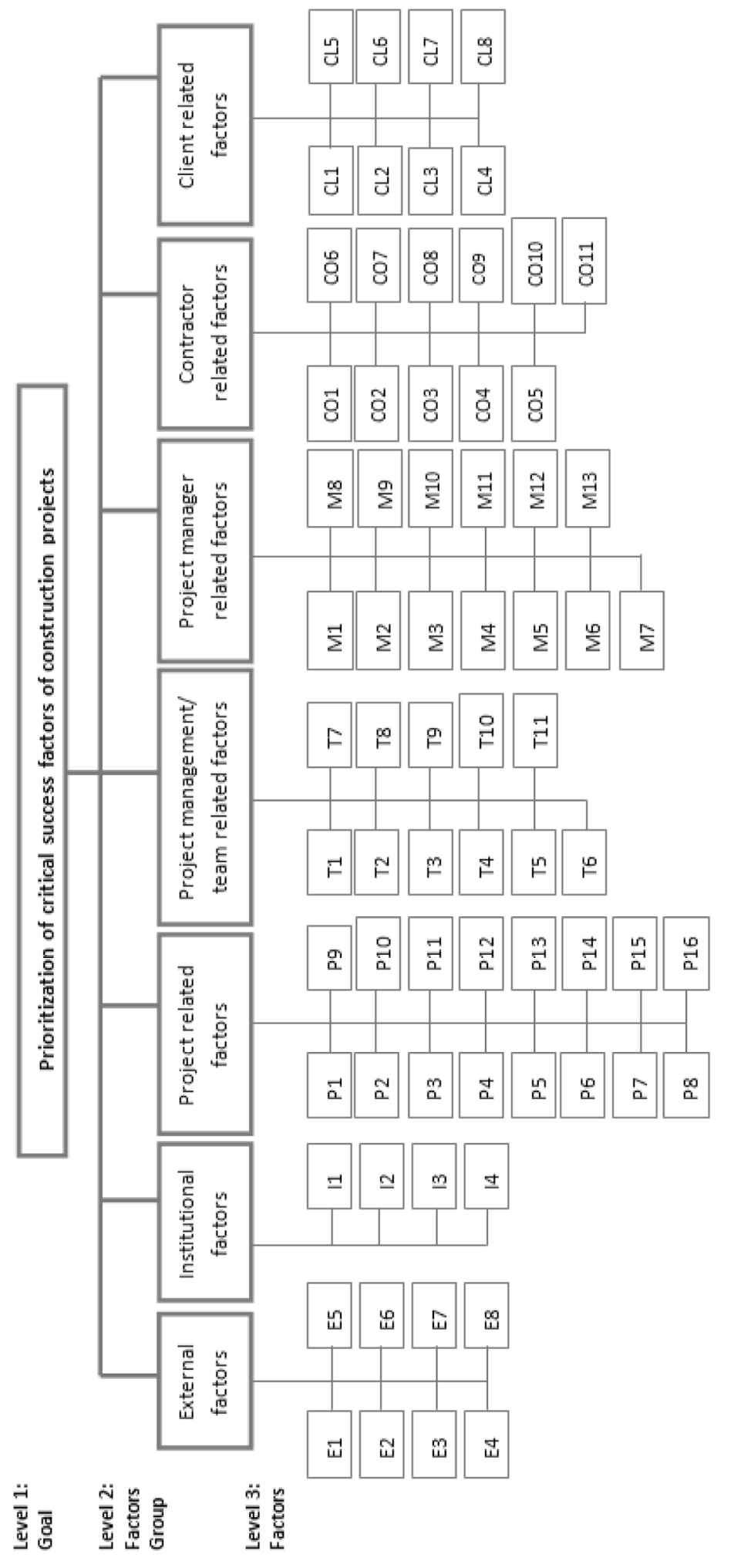

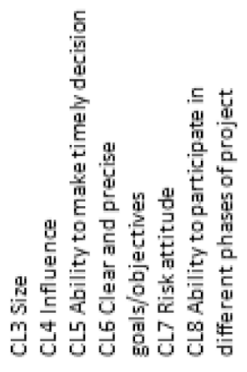
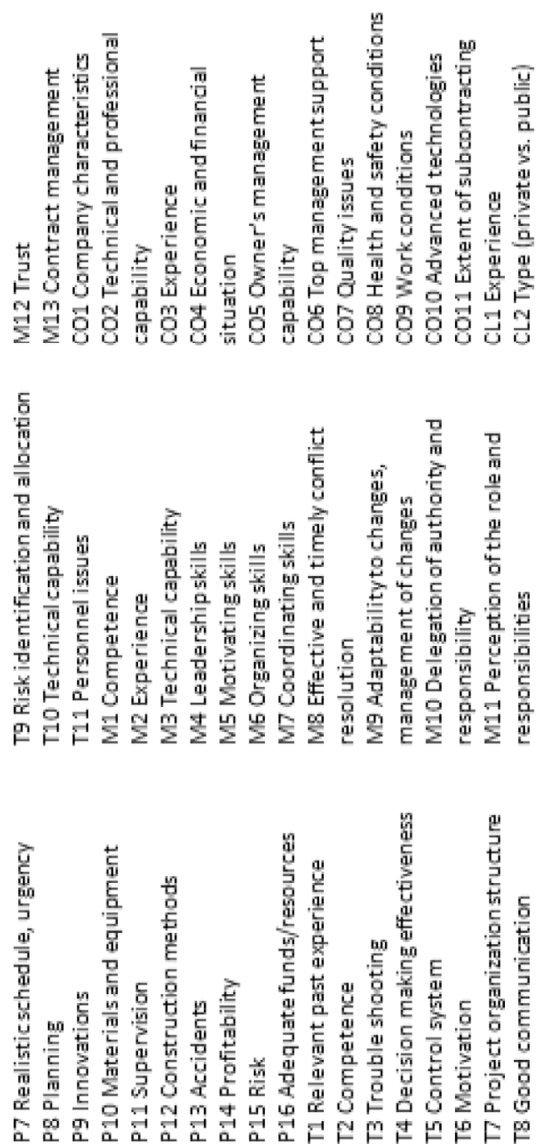

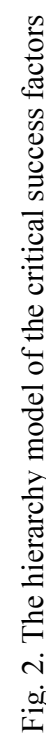


$R_{j},(i, j=1,2, \ldots, m$; where $m$ is the number of factors $)$ are compared with each other in pairs to determine which one in the pair is more important. These comparisons produce a square matrix $\mathbf{A}=\left\|a_{i j}\right\|(i, j=1, \ldots, m)$. The matrix entries $p_{i j}$ may take either the value 0 or 1 ; $a_{i j}=1$ if the factor $R_{i}$ is more important (significant) than $R_{j}$ and, conversely, $a_{i j}=0$ if the factor $R_{j}$ is more important than $R_{i}$. The entries in the main diagonal of the matrix are undefined and represented by dashes, because none of the factors can be compared to itself. It is possible to specify only half of the matrix entries above the main diagonal, because $a_{i j}+a_{j i}=1$. Sum totals $s_{i}=\sum_{j=1}^{m} a_{i j}$ of the entries in each $i^{\text {th }}$ row of the matrix $\mathbf{A}$ and the rank of the $i^{\text {th }}$ factor $r_{i}=m-s_{i}$ have to be calculated. The most important factor gets the rank equal to one. The comparison of factors is of transitive nature: if the factor $R_{i}$ is more important (significant) than $R_{j}$, and $R_{j}$ is more important than $R_{k}$, then $R_{i}$ is more important than $R_{k}$. This way all factors get different ranks.

The decision makers group contains of five senior experts with minimum 10 years' experience in the field of construction project management were invited to fill the AHP survey questionnaire. The results were obtained from all five experts. Experts took approximately five hours to finalize the questionnaire.

Now, we shall compare the main factor groups and demonstrate the method at work. Table 1 lists the comparison results by one expert using only " 0 " and "1".

Table 1. Pairwise comparison of the main factor groups by one expert

\begin{tabular}{c|c|c|c|c|c|c|c|c|c}
\hline Factor Group & 1 & 2 & 3 & 4 & 5 & 6 & 7 & Sum & Rank \\
\hline 1 & - & 0 & 0 & 0 & 0 & 0 & 0 & 0 & 7 \\
2 & 1 & - & 0 & 0 & 0 & 0 & 0 & 1 & 6 \\
3 & 1 & 1 & - & 0 & 1 & 1 & 1 & 5 & 2 \\
4 & 1 & 1 & 1 & - & 1 & 1 & 1 & 6 & 1 \\
5 & 1 & 1 & 0 & 0 & - & 1 & 1 & 4 & 3 \\
6 & 1 & 1 & 0 & 0 & 0 & - & 1 & 3 & 4 \\
7 & 1 & 1 & 0 & 0 & 0 & 0 & - & 2 & 5 \\
\hline
\end{tabular}

Likewise, each expert compared and ranked the factors from all separate groups.

Ranking of the factors makes it easier to apply the Saaty's AHP method with a 9-point scale, where 1 represents "equally important", 3 represents "slightly more important", 5 represents "strongly more important", 7 represents "demonstratedly more important", and, 9 represents "absolutely more important", whereas $2,4,6,8$ denote the degrees of importance between 1 and 3, 3 and 5, 5 and 7, and 7 and 9, respectively (Saaty 1980, 1990; Podvezko 2007, 2009; Podvezko et al. 2010; Wang et al.
2013). All factors $R_{i}$ and $R_{j} \quad(i, j=1,2, \ldots, m$; where $m$ is the number of factors) have to be compared with each other. The comparison produces a square $\operatorname{matrix} \mathbf{P}=\left\|p_{i j}\right\|(i, j=1, \ldots, m)$. The entries $p_{i j}$ in the matrix $\mathbf{P}$ vary between 1 , when both compared factors have equal importance in project implementation, and $p_{i j}=9$, when the factor $R_{i}$ is far more important than the factor $R_{j}$. It is a symmetric inverse matrix, which means $p_{i j}=1 / p_{j i}$.

The weights in Saaty's AHP method - the vector $\boldsymbol{\omega}-$ are normalized components of eigenvector corresponding to the largest eigenvalue $\lambda_{\max }$ of the matrix $\mathbf{P}$ :

$$
P \boldsymbol{\omega}=\lambda_{\max } \omega .
$$

The concordance (consistency) degree of the specific estimates of each expert is determined by the consistency index C.I. and the concordance ratio C.R. (Saaty 1980).

The consistency index is defined as the ratio:

$$
\text { C.I. }=\frac{\lambda_{\max }-m}{m-1},
$$

where: $m$ is the number of the factors compared.

In practice, the level of consistency of the matrix $\mathbf{P}$ may be determined if we compare the calculated consistency index C.I. in the evaluation matrix with randomly generated (against the scale 1-3-5-7-9) random index R.I. found in the same row of the inversely symmetric matrix (Saaty 1980). The ratio of the consistency index C.I. calculated in a particular matrix to the mean value of the random index R.I. is referred to as the consistency ratio $C . R$., assessing the degree of matrix consistency:

$$
\text { C.R. }=\frac{\text { C.I. }}{\text { R.I. }}
$$

The matrix is consistent if the consistency ratio C.R. is smaller than 0.1 (Saaty 1980).

The AHP method was used and each expert filled in a matrix/questionnaire for the pairwise comparison of the factors. Table 2 shows the pairwise comparison of the main factor groups by one expert using the AHP method.

In the expert comparison matrix presented in Table 2, the consistency index C.I. $=0.127$ and the concordance ratio $C . R .=0.096<0.1$, thus the expert's judgement is consistent. Likewise, five other experts compared the factors from all separate groups using the AHP method. The consistency indices and the concordance ratios were calculated for each judgement. Table 3 summarises the pairwise comparison results of the main factor groups by five experts using the AHP method.

Now we shall determine which factors have the biggest impact on project implementation. In addition to a factor's weight within its own group, the impact also depends on the number of factors in the group and on the importance of the group itself (its weight) $\omega_{i}$ among 
Table 2. Pairwise comparison of the main factor groups by on expert using the AHP method

\begin{tabular}{c|c|c|c|c|c|c|c|c|c}
\hline CSF Groups & 1 & 2 & 3 & 4 & 5 & 6 & 7 & Weights & Ranks \\
\hline 1 & 1 & $1 / 3$ & $1 / 8$ & $1 / 9$ & $1 / 7$ & $1 / 6$ & $1 / 4$ & 0.020 & 7 \\
2 & 3 & 1 & $1 / 7$ & $1 / 8$ & $1 / 6$ & $1 / 5$ & $1 / 3$ & 0.031 \\
3 & 8 & 7 & 1 & $1 / 2$ & 3 & 5 & 6 & 0.268 \\
4 & 9 & 8 & 2 & 1 & 4 & 6 & 7 & 0.374 \\
5 & 7 & 6 & $1 / 3$ & $1 / 4$ & 1 & 4 & 5 & 0.166 \\
6 & 6 & 5 & $1 / 5$ & $1 / 6$ & $1 / 4$ & 1 & 4 & 0.093 \\
7 & 4 & 3 & $1 / 4$ & $1 / 7$ & $1 / 5$ & $1 / 4$ & 1 & 0.048 & 5 \\
\hline
\end{tabular}

Table 3. The weights of the factors in the main factor groups determined by five experts

\begin{tabular}{c|c|c|c|c|c|c|c|c|c}
\hline & C.I. & C.R. & 1 & 2 & 3 & 4 & 5 & 6 & 7 \\
\hline 1.(N) & 0.127 & 0.096 & 0.020 & 0.031 & 0.268 & 0.374 & 0.166 & 0.093 & 0.048 \\
2.(R) & 0.024 & 0.018 & 0.035 & 0.044 & 0.053 & 0.126 & 0.154 & 0.310 & 0.278 \\
3.(S) & 0.056 & 0.042 & 0.176 & 0.073 & 0.279 & 0.058 & 0.039 & 0.353 & 0.022 \\
4.(Z) & 0.085 & 0.065 & 0.112 & 0.078 & 0.354 & 0.215 & 0.188 & 0.033 & 0.020 \\
5.(K) & 0.082 & 0.062 & 0.038 & 0.038 & 0.163 & 0.234 & 0.377 & 0.088 & 0.062 \\
Avg. weights & & & 0.086 & 0.065 & 0.227 & 0.197 & 0.139 & 0.198 & 0.092 \\
Ranks & & & 6 & 7 & 1 & 2 & 3 & 4 & 5 \\
\hline
\end{tabular}

Table 4. CSFs ranking with local and global weights

\begin{tabular}{|c|c|c|c|c|c|}
\hline $\begin{array}{l}\text { Level 1: } \\
\text { Goal }\end{array}$ & $\begin{array}{c}\text { Level 2: } \\
\text { Groups of CSFs }\end{array}$ & $\begin{array}{l}\text { Weights } \\
\text { of groups }\end{array}$ & CSFs & $\begin{array}{c}\text { Local } \\
\text { weights }\end{array}$ & $\begin{array}{c}\text { Global } \\
\text { weights }\end{array}$ \\
\hline 1 & 2 & 3 & 4 & 5 & 6 \\
\hline \multirow{39}{*}{$\begin{array}{l}\text { Prioritization } \\
\text { of CSFs of } \\
\text { construction } \\
\text { projects }\end{array}$} & \multirow[t]{8}{*}{ External factors } & \multirow[t]{8}{*}{0.0762} & Economic environment & $0.2269(1)$ & $0.1383(33)$ \\
\hline & & & Social environment & $0.1515(3)$ & $0.0923(48)$ \\
\hline & & & Political environment & $0.1967(2)$ & $0.1199(40)$ \\
\hline & & & Physical environment & $0.0879(6)$ & $0.0536(59)$ \\
\hline & & & Technological environment & $0.1181(5)$ & $0.0720(54)$ \\
\hline & & & Legal environment & $0.1384(4)$ & $0.0844(50)$ \\
\hline & & & Cultural environment & $0.0398(8)$ & $0.0243(71)$ \\
\hline & & & Nature/ecological environment & $0.0407(7)$ & $0.0248(70)$ \\
\hline & \multirow[t]{4}{*}{ Institutional factors } & \multirow[t]{4}{*}{0.0528} & Construction permits & $0.2142(3)$ & $0.0452(65)$ \\
\hline & & & Construction regulations & $0.4218(1)$ & $0.0891(49)$ \\
\hline & & & Product and service certification & $0.2162(2)$ & $0.0457(64)$ \\
\hline & & & Standards & $0.1477(4)$ & $0.0312(69)$ \\
\hline & \multirow{16}{*}{$\begin{array}{l}\text { Project related fac- } \\
\text { tors }\end{array}$} & \multirow[t]{16}{*}{0.2234} & Value & $0.0976(3)$ & $0.3490(7)$ \\
\hline & & & Size & $0.0756(5)$ & $0.2702(13)$ \\
\hline & & & Clear and realistic goals & $0.1250(1)$ & $0.4468(1)$ \\
\hline & & & Project type & $0.0312(14)$ & $0.1117(42)$ \\
\hline & & & Procurement & $0.0384(12)$ & $0.1372(35)$ \\
\hline & & & Complexity and uniqueness & $0.0973(4)$ & $0.3477(8)$ \\
\hline & & & Realistic schedule, urgency & $0.0602(8)$ & $0.2153(21)$ \\
\hline & & & Planning & $0.1160(2)$ & $0.4145(2)$ \\
\hline & & & Innovations & $0.0458(10)$ & $0.1639(26)$ \\
\hline & & & Materials and equipment & $0.0543(9)$ & $0.1942(22)$ \\
\hline & & & Supervision & $0.0387(11)$ & $0.1382(34)$ \\
\hline & & & Construction methods & $0.0357(13)$ & $0.1277(38)$ \\
\hline & & & Accidents & $0.0290(15)$ & $0.1037(45)$ \\
\hline & & & Profitability & $0.0705(6)$ & $0.2521(15)$ \\
\hline & & & Risk & $0.0208(16)$ & $0.0742(52)$ \\
\hline & & & Adequate funds/resources & $0.0638(7)$ & $0.2280(17)$ \\
\hline & \multirow{11}{*}{$\begin{array}{l}\text { Project manage- } \\
\text { ment/team related } \\
\text { factors }\end{array}$} & \multirow[t]{11}{*}{0.2013} & Relevant past experience & $0.1660(1)$ & $0.3677(4)$ \\
\hline & & & Competence & $0.1608(2)$ & $0.3562(5)$ \\
\hline & & & Troubleshooting & $0.0539(9)$ & $0.1195(41)$ \\
\hline & & & Decision-making effectiveness & $0.1042(4)$ & $0.2309(16)$ \\
\hline & & & Control system & $0.0676(8)$ & $0.1498(32)$ \\
\hline & & & Motivation & $0.1006(5)$ & $0.2229(19)$ \\
\hline & & & Project organization structure & $0.0701(7)$ & $0.1553(30)$ \\
\hline & & & Good communication & $0.1237(3)$ & $0.2741(12)$ \\
\hline & & & Risk identification and allocation & $0.0477(10)$ & $0.1056(44)$ \\
\hline & & & Technical capability & $0.0851(6)$ & $0.1885(23)$ \\
\hline & & & Personnel issues & $0.0200(11)$ & $0.0443(66)$ \\
\hline
\end{tabular}


Continued Table 4

\begin{tabular}{|c|c|c|c|c|c|}
\hline $\begin{array}{l}\text { Level 1: } \\
\text { Goal }\end{array}$ & $\begin{array}{c}\text { Level 2: } \\
\text { Groups of CSFs }\end{array}$ & $\begin{array}{l}\text { Weights } \\
\text { of groups }\end{array}$ & CSFs & $\begin{array}{c}\text { Local } \\
\text { weights }\end{array}$ & $\begin{array}{c}\text { Global } \\
\text { weights }\end{array}$ \\
\hline 1 & 2 & 3 & 4 & 5 & 6 \\
\hline & \multirow{13}{*}{$\begin{array}{l}\text { Project manager } \\
\text { related factors }\end{array}$} & \multirow[t]{13}{*}{0.1848} & Competence & $0.1637(1)$ & $0.3933(3)$ \\
\hline & & & Experience & $0.1277(2)$ & $0.3068(9)$ \\
\hline & & & Technical capability & $0.0750(6)$ & $0.1802(25)$ \\
\hline & & & Leadership skills & $0.0658(8)$ & $0.1580(29)$ \\
\hline & & & Motivating skills & $0.0404(11)$ & $0.0970(47)$ \\
\hline & & & Organizing skills & $0.0948(4)$ & $0.2278(18)$ \\
\hline & & & Coordinating skills & $0.0772(5)$ & $0.1856(24)$ \\
\hline & & & Effective and timely conflict resolution & $0.0568(9)$ & $0.1364(36)$ \\
\hline & & & $\begin{array}{l}\text { Adaptability to changes, management of } \\
\text { changes }\end{array}$ & $0.1207(3)$ & $0.2899(11)$ \\
\hline & & & Delegation of authority and responsibility & $0.0676(7)$ & $0.1625(27)$ \\
\hline & & & Perception of the role and responsibilities & $0.0272(13)$ & $0.0652(57)$ \\
\hline & & & Trust & $0.0287(12)$ & $0.0689(56)$ \\
\hline & & & Contract management & $0.0544(10)$ & $0.1307(37)$ \\
\hline & \multirow[t]{8}{*}{ Client related factors } & \multirow[t]{8}{*}{0.1755} & Experience & $0.1579(4)$ & $0.2217(20)$ \\
\hline & & & Type (private vs. public) & $0.0316(8)$ & $0.0443(67)$ \\
\hline & & & Size & $0.0366(7)$ & $0.0514(60)$ \\
\hline & & & Influence & $0.0492(6)$ & $0.0691(55)$ \\
\hline & & & Ability to make timely decisions & $0.2132(2)$ & $0.2992(10)$ \\
\hline & & & Clear and precise goals/objectives & $0.2503(1)$ & $0.3513(6)$ \\
\hline & & & Risk attitude & $0.0698(5)$ & $0.0980(46)$ \\
\hline & & & $\begin{array}{l}\text { Ability to participate in different phases of } \\
\text { project }\end{array}$ & $0.1914(3)$ & $0.2686(14)$ \\
\hline & \multirow{11}{*}{$\begin{array}{l}\text { Contractor related } \\
\text { factors }\end{array}$} & \multirow[t]{11}{*}{0.0860} & Company characteristics & $0.0873(5)$ & $0.0826(51)$ \\
\hline & & & Technical and professional capability & $0.1638(2)$ & $0.1550(31)$ \\
\hline & & & Experience & $0.1708(1)$ & $0.1616(28)$ \\
\hline & & & Economic and financial situation & $0.1349(3)$ & $0.1276(39)$ \\
\hline & & & Owner's management capability & $0.0339(11)$ & $0.0320(68)$ \\
\hline & & & Top management support & $0.0774(6)$ & $0.0732(53)$ \\
\hline & & & Quality issues & $0.1171(4)$ & $0.1108(43)$ \\
\hline & & & Health and safety conditions & $0.0516(9)$ & $0.0488(62)$ \\
\hline & & & Work conditions & $0.0506(10)$ & $0.0479(63)$ \\
\hline & & & Advanced technologies & $0.0600(7)$ & $0.0568(58)$ \\
\hline & & & Extent of subcontracting & $0.0526(8)$ & $0.0497(61)$ \\
\hline
\end{tabular}

other groups. To make sure that the conditions are equal for all factors, irrespective of their group, the weights $\omega_{i j}$ of the $j^{\text {th }}$ factor of each $i^{\text {th }}$ group have to be multiplied by the number of factors in the group $n_{j}$.

Then, in all groups, the average weight $1 / n_{j}$ will have the same value equal to one. The weight $\omega_{i}$ of the $i^{\text {th }}$ group also affects the importance. The final impact on project implementation is, therefore, defined by the value:

$$
\tilde{\omega}_{i j}=\omega_{i} \omega_{i j} n_{j} .
$$

The factors with the biggest impact on project implementation are singled out by the highest calculated value $\tilde{\omega}_{i j}$.

CSFs with local and global weights are ranked in Table 4. The top ten critical success factors for construction projects in Lithuania are: (1) clear and realistic project goals, (2) project planning, (3) project manager's competence, (4) relevant past experience of the project management/team, (5) the competence of the project management/team, (6) clear and precise goals/objectives of the client, (7) the value of the project, (8) the complexity and uniqueness of the project, (9) the project manager's experience, and (10) the client's ability to make timely decisions. Four of these factors related to the project are "hard" elements of the project success. The rest of the factors may be classified as "soft" or humanrelated factors of the project success.

\section{Conclusions}

This paper proposes the AHP approach as a tool to rank different critical success factors for construction projects. AHP is a powerful and flexible method that uses a hierarchic structure to present a complex decision problem by decomposing it into several smaller subproblems. The technique seems to perform better than results based purely on the experts' assignation of the absolute priorities of each criterion (Zahedi 1986) or than results based just on qualitative analysis. The AHP method, however, is time consuming and its use is, therefore, limited.

Our study revealed that the highest ranking CSFs for construction projects in Lithuania are: (1) clear and realistic project goals, (2) project planning, (3) project manager's competence, (4) relevant past experience of the project management/team, (5) the competence of the project management/team, (6) clear and precise goals/objectives of the client, (7) the value of the project, 
(8) the complexity and uniqueness of the project, (9) the project manager's experience, and (10) the client's ability to make timely decisions.

Based on these findings, the study highlighted the key areas for successful implementation of construction projects in Lithuania. It may be concluded that clear and realistic project goals and project planning play the key role in successful implementation of construction projects in Lithuania. They should be supported by the top project management, clear and precise goals/objectives of the client, and, finally, by the client's ability to make timely decisions. The findings would be valuable for future studies in this area.

The weights of the CSFs calculated by using AHP can be later used to rank different construction projects. Various methods may be used for the purpose.

The research would benefit from a larger sample for the questionnaire survey. This would increase the general credibility and wider applicability of the findings.

\section{References}

Ahmed, R.; Azmi, N.; Masood, T.; Tahir, M.; Ahmad, M. S. 2013. What does project leadership really do?, International Journal of Scientific \& Engineering Research 4(1): 1-8.

Aksorn, T.; Hadikusumo, B. H. W. 2008. Critical success factors influencing safety program performance in Thai construction projects, Safety Science 46: 709-727. http://dx.doi.org/10.1016/j.ssci.2007.06.006

Al Haadir, S.; Panuwatwanich, K. 2011. Critical success factors for safety program implementation among construction companies in Saudi Arabia, Procedia Engineering 14: 148-155. http://dx.doi.org/10.1016/j.proeng.2011.07.017

Al-Tmeemy, S. M. H. M.; Abdul-Rahman, H.; Harun, Z. 2010. Future criteria for success of building projects in Malaysia, International Journal of Project Management 29(3): 337348. http://dx.doi.org/10.1016/j.ijproman.2010.03.003

Alzahrani, J. I.; Emsley, M. W. 2013. The impact of contractors' attributes on construction project success: a post construction evaluation, International Journal of Project Management 31(2): 313-322.

http://dx.doi.org/10.1016/j.ijproman.2012.06.006

Aminbakhsh, S.; Gunduz, M.; Sonmez, R. 2013. Safety risk assessment using analytic hierarchy process (AHP) during planning and budgeting of construction projects, Journal of Safety Research 46: 99-105.

http://dx.doi.org/10.1016/j.jsr.2013.05.003

Bitarafan, M.; Hashemkhani Zolfani, S.; Arefi, S. L.; Zavadskas, E. K. 2012. Evaluating the construction methods of cold-formed steel structures in reconstructing the areas damaged in natural crises, using the methods AHP and COPRAS-G, Archives of Civil and Mechanical Engineering 12(3): 360-367.

http://dx.doi.org/10.1016/j.acme.2012.06.015

Cheng, A.-C. 2013. A fuzzy multiple criteria comparison of technology valuation methods for the new materials development, Technological and Economic Development of Economy 19(3): 397-408. http://dx.doi.org/10.3846/20294913.2013.821687

Chou, J. S.; Pham, A. D.; Wang, H. 2013. Bidding strategy to support decision-making by integrating fuzzy AHP and regression-based simulation, Automation in Construction 35: 517-527.

http://dx.doi.org/10.1016/j.autcon.2013.06.007
Doloi, H.; Sawhney, A.; Iyer, K. C.; Rentala, S. 2012. Analysing factors affecting delays in Indian construction projects, International Journal of Project Management 30(4): 479-489. http://dx.doi.org/10.1016/j.ijproman.2011.10.004

Fouladgar, M. M.; Yazdani-Chamzini, A.; Lashgari, A.; Zavadskas, E. K.; Turskis, Z. 2012. Maintenance strategy selection using AHP and COPRAS under fuzzy environment, International Journal of Strategic Property Management 16(1): 85-104.

http://dx.doi.org/10.3846/1648715X.2012.666657

Garbharran, H.; Govender, J.; Msani, T. 2012. Critical success factors influencing project success in the construction industry, Acta Structilia 19(2): 90-108.

Ghoddousi, P.; Hosseini, M. R. 2012. A survey of the factors affecting the productivity of construction projects in Iran, Technological and Economic Development of Economy 18(1): 99-116. http://dx.doi.org/10.3846/20294913.2012.661203

Government of the Republic of Lithuania. 2013. Dèl Lietuvos Respublikos Vyriausybès 2004 m. rugsejo 23 d. nutarimo Nr. 1213 „Dèl Daugiabučių namų atnaujinimo (modernizavimo) programos ir Valstybès paramos daugiabučiams namams modernizuoti teikimo ir investicijuc projektų energinio efektyvumo nustatymo taisykliu patvirtinimo“" pakeitimo, Valstybès žinios, 2013, Nr. 83-4153 (in Lithuanian).

Gudiené, N.; Banaitis, A.; Banaitienè, N. 2013. Evaluation of critical success factors for construction projects - an empirical study in Lithuania, International Journal of Strategic Property Management 17(1): 21-31. http://dx.doi.org/10.3846/1648715X.2013.787128

Hashemkhani Zolfani, S.; Chen, I.-S.; Rezaeiniya, N.; Tamošaitiene, J. 2012. A hybrid MCDM model encompassing AHP and COPRAS-G methods for selecting company supplier in Iran, Technological and Economic Development of Economy 18(3): 529-543. http://dx.doi.org/10.3846/20294913.2012.709472

Huang, X. 2011. An analysis of the selection of project contractor in the construction management process, International Journal of Business and Management 6(3): 184-189.

Hwang, B.-G.; Ng, W. J. 2013. Project management knowledge and skills for green construction: overcoming challenges, International Journal of Project Management 31(2): 272284. http://dx.doi.org/10.1016/j.ijproman.2012.05.004

Hwang, B.-G.; Zhao, X.; Ng, S. Y. 2013. Identifying the critical factors affecting schedule performance of public housing projects, Habitat International 38: 214-221. http://dx.doi.org/10.1016/j.habitatint.2012.06.008

Ibrahim, K. I.; Costello, S. B.; Wilkinson, S. 2013. Key practice indicators of team integration in construction projects: a review, Team Performance Management 19(3-4): 132152. http://dx.doi.org/10.1108/TPM-10-2012-0033

Ismail, Z.; Doostdar, S.; Harun, Z. 2012. Factors influencing the implementation of a safety management system for construction sites, Safety Science 50(3): 418-423. http://dx.doi.org/10.1016/j.ssci.2011.10.001

Kuzman, M. K.; Grošelj, P.; Ayrilmis, N.; ZbašnikSenegačnik, M. 2013. Comparison of passive house construction types using analytic hierarchy process, Energy and Buildings 64: 258-263. http://dx.doi.org/10.1016/j.enbuild.2013.05.020 
Lai, J. H. K. 2012. Analytical assessment and comparison of facilities management services for residential estates, International Journal of Strategic Property Management 16(3): 236-253.

http://dx.doi.org/10.3846/1648715X.2012.682183

Memon, A. H.; Rahman, I. A.; Aziz, A. A. A.; Abdullah, N. H. 2012. Using structural equation modelling to assess effects of construction resource related factors on cost overrun, World Applied Sciences Journal (Mathematical Applications in Engineering) 21: 6-15.

http://dx.doi.org/10.5829/idosi.wasj.2012.20.mae.9995

Meng, X. 2012. The effect of relationship management on project performance in construction, International Journal of Project Management 30(2): 188-198.

http://dx.doi.org/10.1016/j.ijproman.2011.04.002

Nguyen, T. A.; Chovichien, V.; Takano, Sh. 2013. Quantitative weighting for evaluation indexes of construction project success by application of structural equation modelling, International Journal of Construction Engineering and Management 2(3): 70-84.

http://dx.doi.org/10.5923/j.ijcem.20130203.05

Nixon, P.; Harrington, M.; Parker, D. 2012. Leadership performance is significant to project success or failure: a critical analysis, International Journal of Productivity and Performance Management 61(2): 204-216. http://dx.doi.org/10.1108/17410401211194699

Podvezko, V. 2007. Determining the level of agreement of expert estimates, International Journal of Management and Decision Making 8(5-6): 586-600. http://dx.doi.org/10.1504/IJMDM.2007.013420

Podvezko, V. 2009. Application of AHP techniques, Journal of Business Economics and Management 10(2): 181-189. http://dx.doi.org/10.3846/1611-1699.2009.10.181-189

Podvezko, V.; Mitkus, S.; Trinkūnienè, E. 2010. Complex evaluation of contracts for construction, Journal of Civil Engineering and Management 16(2): 287-297. http://dx.org/10.3846/jcem.2010.33

Raisbeck, P.; Tang, L. C. M. 2013. Identifying design development factors in Australian PPP projects using an AHP framework, Construction Management and Economics 31(1): 20-39. http://dx.org/10.1080/01446193.2012.729133

Rezaeiniya, N.; Hashemkhani Zolfani, S.; Zavadskas, E. K. 2012. Greenhouse locating based on ANP-COPRAS-G methods - an empirical study based on Iran, International Journal of Strategic Property Management 16(2): 188200. http://dx.doi.org/10.3846/1648715X.2012.686459

Ribeiro, P.; Paiva, A.; Varajão, J.; Dominguez, C. 2013. Success evaluation factors in construction project management - some evidence from medium and large Portuguese companies, KSCE Journal of Civil Engineering 17(4): 603-609. http://dx.doi.org/10.1007/s12205-013-0019-4

Rockart, J. F. 1982. The changing role of the information systems executive: a critical success factors perspective, Sloan Management Review 24(1): 3-13.

Saaty, T. L. 1980. The analytic hierarchy process. Planning, priority setting, resource allocation. New York: McGrawHill. 287 p.

Saaty, T. L. 1990. How to make a decision: the analytic hierarchy process, European Journal of Operational Research 48(1): 9-26.

http://dx.doi.org/10.1016/0377-2217(90)90057-I
Sotoodeh Gohar, A.; Khanzadi, M.; Farmani, M. 2012. Identifying and evaluating risks of construction projects in fuzzy environment: a case study in Iranian construction industry, Indian Journal of Science and Technology 5(11): 3593-3602.

Statistics Lithuania. 2013a. Structure of gross value added by production approach by economic activity [online], [cited 6 January 2014]. Economy and finance. Statistics Lithuania. Available from Internet: http://osp.stat.gov.lt/en/rodikliai38

Statistics Lithuania. 2013b. Employment and unemployment [online], [cited 6 January 2014]. Population and social statistics. Statistics Lithuania. Available from Internet: http://osp.stat.gov.lt/en/rodikliai9

Tan, D. J.-Z.; Ghazali, F. E. M. 2011. Critical success factors for Malaysian contractors in international construction projects using Analytical Hierarchy Process, International Conference on Engineering, Project, and Production Management EPPM, 20-21 September, 2011, Singapore, $127-138$

Wang, W. C.; Yu, W. D.; Yang, I.-T.; Lin, C. C.; Lee, M. T.; Cheng, Y. Y. 2013. Applying the AHP to support the best-value contractor selection - lessons learned from two case studies in Taiwan, Journal of Civil Engineering and Management 19(1): 24-36.

http://dx.doi.org/10.3846/13923730.2012.734851

Yang, L. R.; Chen, J. H.; Wang, H. W. 2012. Assessing impacts of information technology on project success through knowledge management practice, Automation in Construction 22: 182-191.

http://dx.doi.org/10.1016/j.autcon.2011.06.016

Yang, L. R.; Huang, C. F.; Wu, K. S. 2011. The association among project manager's leadership style, teamwork and project success, International Journal of Project Management 29(3): 258-267. http://dx.doi.org/10.1016/j.ijproman.2010.03.006

Yazdani-Chamzini, A.; Fouladgar, M. M.; Zavadskas, E. K.; Moini, S. H. H. 2013. Selecting the optimal renewable energy using multi criteria decision making, Journal of Business Economics and Management 14(5): 957-978. http://dx.doi.org/10.3846/16111699.2013.766257

Yong, Y. C.; Mustaffa, N. E. 2012. Analysis of factors critical to construction project success in Malaysia, Engineering, Construction and Architectural Management 19(5): 543556. http://dx.doi.org/10.1108/09699981211259612

Yong, Y. C.; Mustaffa, N. E. 2013. Critical success factors for Malaysian construction projects: an empirical assessment, Construction Management and Economics 31(9): 959978. http://dx.doi.org/10.1080/01446193.2013.828843

Zahedi, F. 1986. The analytic hierarchy process: a survey of the method and its applications, Interfaces 16(4): 96-108.

Zavadskas, E. K.; Kaklauskas, A. 2007. Mehrzielselektion für Entscheidungen im Bauwesen. Stuttgart: IRB Verlag. $276 \mathrm{p}$.

Zavadskas, E. K.; Vainiūnas, P.; Turskis, Z.; Tamošaitienè, J. 2012. Multiple criteria decision support system for assessment of projects managers in construction, International Journal of Information Technology \& Decision Making 11(2): 501-520. http://dx.doi.org/10.1142/S0219622012400135

Zavadskas, E. K.; Vilutienė, T.; Turskis, Z.; Šaparauskas, J. 2014. Multi-criteria analysis of projects' performance in construction, Archives of Civil and Mechanical Engineering 14(1): 114-121.

http://dx.doi.org/10.1016/j.acme.2013.07.006 
Neringa GUDIENE். A PhD student in the Department of Construction Economics and Property Management at Vilnius Gediminas Technical University. Her research interests include construction project performance, critical success factors, multiple criteria decision making.

Audrius BANAITIS. Associate Professor in the Department of Construction Economics and Property Management at Vilnius Gediminas Technical University. His research interests include project/risk management and project success, property management, sustainability and construction industry development, multiple criteria decision making: applications in construction.

Valentinas PODVEZKO. Professor in the Department of Mathematical Statistics at Vilnius Gediminas Technical University. He is an author of more than 120 publications. His research interests include decision-making theory, expert systems, mathematical methods in modelling socio-economic, technological and engineering processes, hierarchical structuring of complex entities, sampling and forecasting models, simulation and stability of mathematical models.

Nerija BANAITIENÉ. Associate Professor in the Department of Construction Economics and Property Management at Vilnius Gediminas Technical University. Her research interests include project/risk management, total quality management, building life cycle analysis, multiple criteria decision making: applications in construction. 